Article

\title{
Cumulative Environmental Effects of Hydropower Stations Based on the Water Footprint Method-Yalong River Basin, China
}

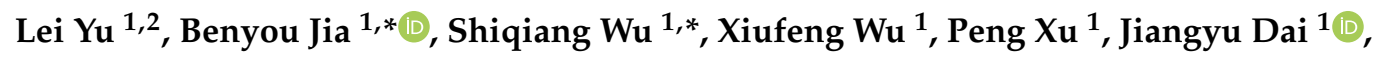 \\ Fangfang Wang ${ }^{1}$ and Liming $\mathrm{Ma}^{3}$ \\ 1 State Key Laboratory of Hydrology-Water Resources and Hydraulic Engineering, \\ Nanjing Hydraulic Research Institute, Nanjing 210029, China; yulei0405@foxmail.com (L.Y.); \\ xfwu@nhri.cn (X.W.); xupeng1124@foxmail.com (P.X.); jydai@nhri.cn (J.D.); ffwang@nhri.cn (F.W.) \\ 2 College of Water Conservancy and Hydropower Engineering, Hohai University, Nanjing 210098, China \\ 3 Yellow River Engineering Consulting Co. Ltd., Zhengzhou 450003, China; malm@yrec.cn \\ * Correspondence: byjia@nhri.cn (B.J.); sqwu@nhri.cn (S.W.); \\ Tel.: +86-159-5057-4091 (B.J.); +86-138-5156-8908 (S.W.)
}

Received: 30 September 2019; Accepted: 22 October 2019; Published: 25 October 2019

\begin{abstract}
The construction of hydropower stations is not without controversy as they have a certain degree of impact on the ecological environment. Moreover, the water footprint and its cumulative effects on the environment (The relationship between the degree of hydropower development and utilization in the basin and the environment) of the development and utilization of cascade hydropower stations are incompletely understood. In this paper, we calculate the evaporated water footprint (EWF, water evaporated from reservoirs) and the product water footprint of hydropower stations (PWF, water consumption per unit of electricity production), and the blue water scarcity (BWS, the ratio of the total blue water footprint to blue water availability) based on data from 19 selected hydropower stations in the Yalong River Basin, China. Results show that: (a) the EWFs in established, ongoing, proposed, and planning phases of 19 hydropower stations are 243, 123, 59, and $42 \mathrm{Mm}^{3}$, respectively; (b) the PWF of 19 hydropower stations varies between 0.01 and $4.49 \mathrm{~m}^{3} \mathrm{GJ}^{-1}$, and the average PWF is $1.20 \mathrm{~m}^{3} \mathrm{GJ}^{-1}$. These values are quite small when compared with hydropower stations in other basins in the world, and the difference in PWF among different hydropower stations is mainly derived from energy efficiency factor; (c) all the BWS in the Yalong River Basin are below $100 \%$ (low blue water scarcity), in which the total blue water footprint is less than $20 \%$ of the natural flow, and environmental flow requirements are met. From the perspective of the water footprint method, the cumulative environmental effects of hydropower development and utilization in the Yalong River Basin will not affect the local environmental flow requirements.
\end{abstract}

Keywords: cascade hydropower development; Yalong river basin; cumulative environmental effect; water footprint

\section{Introduction}

As a clean and renewable energy source, hydropower meets the growing energy needs of mankind while mitigating global warming trends [1]. Hydropower continues to grow worldwide, especially in developing countries, such as China [2]. However, large-scale hydropower development and construction has also brought controversies [3-7], such as the effects on the water environment and the changes to the river hydrological, including runoff, flood peak flow, water temperature [8]; effects on the ecological environment, such as migratory fish breeding [9], environmental flow [10], and ecological compensation [11-13]; effects on the social environment, such as immigration issues 
and land occupation issues [14]. In addition, the risk and the environmental impact of dam break are not negligible $[15,16]$. The traditional water resource index "water intake" can no longer truly measure the water consumption of hydropower stations and their positive and negative impacts on the environment, ecology, and society. Therefore, how to objectively measure the comprehensive performance of cascade hydropower development is a difficult problem [17].

The water footprint (WF) is a method to quantify the water consumption of hydropower stations and reservoirs and to assess the increasing pressure on local water resources considering the water surface evaporation of the reservoir (i.e., blue water footprint) $[18,19]$. The water footprint concept is based on virtual water, proposed by Dutch scholar Hoekstra in 2002 and is an indicator of water use by consumers or producers, including direct and indirect water use [20]. The water footprint consists of three parts: green water (soil water), blue water (surface water and groundwater), and grey water (polluted water).

The product water footprint (PWF) of hydropower plants characterizes the water consumption per unit of electricity production. There are three main calculation methods, which are the gross water consumption method, the net water consumption method, and the water balance method [21-25], respectively, involving spatial scales such as the world, countries, and river basins. For example, Mekonnen et al. [23] calculated the PWF of hydropower plants on a global scale using the total water consumption method, and the PWF ranges from 0.3 to $850 \mathrm{~m}^{3} \mathrm{GJ}^{-1}$, and the average PWF is $68 \mathrm{~m}^{3} \mathrm{GJ}^{-1}$. The calculation accuracy is questionable because only 35 hydropower stations were selected for the whole world. Herath et al. [24] used the water balance method to calculate the PWF of 17 hydropower stations in New Zealand, and the calculated results range from -2.80 to $19.80 \mathrm{~m}^{3} \mathrm{GJ}^{-1}$. However, WF is an indicator for quantifying the use of freshwater, and there should be no negative values. Therefore, the water balance method is not suitable for calculating the PWF.

Primary energy plays an important role in the primary stage of the energy supply chain, including raw coal, crude oil, natural gas, biomass, hydropower, nuclear energy, wind energy, and solar energy. These energy development and utilization processes have different levels of consumption of water resources. Gerbens-Leenes et al. [26] estimated the biomass water footprint of four countries (the Netherlands, the United States, Brazil, and Zimbabwe) with an average of $72 \mathrm{~m}^{3} \mathrm{GJ}^{-1}$, which is the largest energy source in primary energy consumption. Gleick [27] estimated raw coal, crude oil, natural gas, nuclear energy, wind energy, and solar water footprint. The wind power water footprint is negligible, and the value is $0 \mathrm{~m}^{3} \mathrm{GJ}^{-1}$. Monthly blue water scarcity in the basin is defined as the ratio of the total blue WF of the basin over the month to the available blue WF [28]. Currently, there are various monthly water scarcity studies for specific river basins (Heihe River Basin [29] and Yellow River Basin [19] in China), national-level (China [18] and Morocco [30]), transboundary-level [31], and global-level [28]. However, those studies paid less attention to water consumption and accumulated blue water scarcity at different phases of the development and utilization of cascade hydropower stations in the basin.

Based on the water footprint method, this paper takes the Yalong River Basin as the research object, considers the four phases of hydropower development in the basin, calculates the PWF and the blue water scarcity, analyzes its influencing factors, and evaluates the cumulative environmental effects of hydropower stations (The relationship between the degree of hydropower development and utilization in the basin and the environment).

\section{Materials and Methods}

\subsection{Study Area}

The Yalong River is the largest tributary of the Jinsha River in China, with a total length of $1571 \mathrm{~km}$, natural drop of $3830 \mathrm{~m}$, annual runoff of 60.9 billion $\mathrm{m}^{3}$, drainage basin area of approximately $136,000 \mathrm{~km}^{2}$, and the average annual precipitation of 500 to $2470 \mathrm{~mm}$. The temperature in the basin 
increases from north to south, and the average annual temperature is -4.9 to $19.7^{\circ} \mathrm{C}$. The average annual relative humidity is not much different, and the downstream is slightly higher than the upstream [32].

The basin is rich in hydropower resources, which is one of the thirteen state hydropower bases in China. According to the comprehensive planning of the river basin, the Yalong mainstream planning is divided into four stages, namely the established phase I ( 5 hydropower stations, which are Jinping I, Jinping II, Guandi, Ertan, and Tongzilin), the ongoing phase II (2 power stations, which are Lianghekou and Yangfanggou), the proposed phase III (5 power stations, which are Yagen I, Yagen II, Lenggu, Mengdigou, and Kara) and the planning phase IV (7 power stations, which are Muluo, Renda, Linda, Lean, Xinlong, Gongke, and Jiaxi), which can develop 19 large and medium-sized cascade hydropower stations with good reservoir regulation performance and an installed capacity of about 30 million $\mathrm{kW}$ (Table 1). The key parameters and locations of the 19 cascade hydropower stations and the locations of 5 evaporation stations are shown in Table 1 and Figure 1.

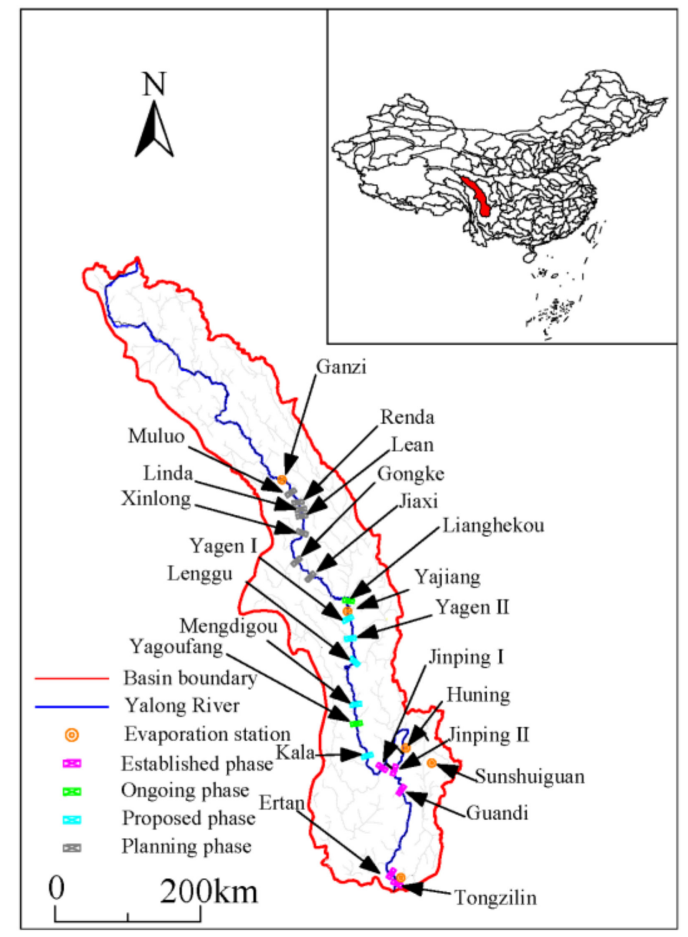

Figure 1. Location, river network, evaporation stations, and cascaded hydropower stations of the Yalong River Basin.

Table 1. Properties of 19 hydropower stations on the Yalong River.

\begin{tabular}{|c|c|c|c|c|c|c|}
\hline \multirow{2}{*}{$\begin{array}{l}\text { Hydropower } \\
\text { Station }\end{array}$} & \multirow{2}{*}{$\begin{array}{l}\text { Reservoir Water } \\
\text { Surface Area/ha }\end{array}$} & \multicolumn{2}{|c|}{ Evaporation } & \multirow{2}{*}{$\begin{array}{c}\text { Installed } \\
\text { Capacity/MW }\end{array}$} & \multirow{2}{*}{$\begin{array}{c}\text { Annual Generation } \\
\text { Capacity/10 } 10^{8} \mathrm{Kwh}\end{array}$} & \multirow{2}{*}{$\begin{array}{c}\text { Product } \\
W F / \mathrm{m}^{3} \mathrm{GJ}^{-1}\end{array}$} \\
\hline & & $\mathrm{mm} \mathrm{yr}^{-1}$ & $\mathrm{~m}^{3} \mathrm{yr}^{-1}$ & & & \\
\hline Muluo & 870 & 903.97 & 786455.64 & 160 & 7.16 & 0.31 \\
\hline Renda & 10190 & 903.97 & 9208853.16 & 400 & 18.15 & 1.41 \\
\hline Linda & 870 & 903.97 & 786455.64 & 144 & 6.59 & 0.33 \\
\hline Lean & 870 & 903.97 & 786455.64 & 99 & 4.52 & 0.48 \\
\hline Xinlong & 10190 & 903.97 & 9208853.16 & 220 & 10.11 & 2.53 \\
\hline Gongke & 10190 & 1046.27 & 10658457.12 & 400 & 17.16 & 1.73 \\
\hline Jiaxi & 10190 & 1046.27 & 10658457.12 & 360 & 16.19 & 1.83 \\
\hline Lianghekou & 109020 & 1046.27 & 114064355.4 & 3000 & 108.9 & 2.91 \\
\hline Yagen I & 14690 & 1046.27 & 15369706.3 & 214 & 9.51 & 4.49 \\
\hline Yagen II & 10190 & 1046.27 & 10658457.12 & 990 & 44.33 & 0.67 \\
\hline Lenggu & 10190 & 1046.27 & 10658457.12 & 2718 & 124.68 & 0.24 \\
\hline Mengdigou & 14690 & 905.11 & 13296065.9 & 2200 & 89.30 & 0.41 \\
\hline Yangfanggou & 10190 & 905.11 & 9220446.08 & 1500 & 69.43 & 0.37 \\
\hline Kala & 10190 & 905.11 & 9220446.08 & 1000 & 51.64 & 0.50 \\
\hline
\end{tabular}


Table 1. Cont.

\begin{tabular}{|c|c|c|c|c|c|c|}
\hline \multirow{2}{*}{$\begin{array}{l}\text { Hydropower } \\
\text { Station }\end{array}$} & \multirow{2}{*}{$\begin{array}{l}\text { Reservoir Water } \\
\text { Surface Area/ha }\end{array}$} & \multicolumn{2}{|c|}{ Evaporation } & \multirow{2}{*}{$\begin{array}{c}\text { Installed } \\
\text { Capacity/MW }\end{array}$} & \multirow{2}{*}{$\begin{array}{l}\text { Annual Generation } \\
\text { Capacity } / 10^{8} \mathrm{Kwh}\end{array}$} & \multirow{2}{*}{$\begin{array}{c}\text { Product } \\
\mathrm{WF} / \mathrm{m}^{3} \mathrm{GJ}^{-1}\end{array}$} \\
\hline & & $\mathrm{mm} \mathrm{yr}^{-1}$ & $\mathrm{~m}^{3} \mathrm{yr}^{-1}$ & & & \\
\hline Jinping I & 82550 & 905.11 & 74716830.5 & 3600 & 180.90 & 1.15 \\
\hline Jinping II & 870 & 905.11 & 787445.7 & 4800 & 258.80 & 0.01 \\
\hline Guandi & 14690 & 905.11 & 13296065.9 & 2400 & 99.50 & 0.37 \\
\hline Ertan & 100600 & 1454.43 & 146315658 & 3300 & 176.70 & 2.30 \\
\hline Tongzilin & 5600 & 1454.43 & 8144808 & 600 & 30.20 & 0.75 \\
\hline
\end{tabular}

\subsection{Methods}

\subsubsection{EWF of Hydropower Stations}

The evaporated water footprint (EWF, water evaporated from reservoirs) is calculated by accounting for the total evaporation of the reservoir area [23]. It is noted that there was evaporation from the original flowing river before the reservoir was constructed. However, the evaporation from the original flowing river is likely omitted in a mountainous river, since the reservoir area is generally much larger than the river's original area. In addition, the reservoirs of the Yalong River are mainly for power generation and flood control. Therefore, this paper does not consider the allocation coefficient of water footprint for functions such as irrigation and water supply [18].

The EWF $\left(\mathrm{m}^{3}\right)$ is equal to its annual water evaporation from the surface area:

$$
E W F=10 \times h_{E} \times A,
$$

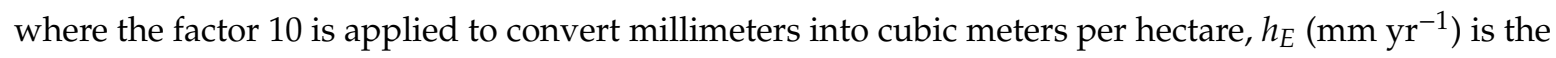
water evaporation from the surface of the reservoir and $A(h a)$ is the surface area of the reservoir.

\subsubsection{PWF of Hydropower Stations}

The product water footprint (PWF) of hydropower stations is defined as the volume of freshwater used to produce electric power at the hydropower station, which means the blue water consumption per unit of electricity production $\left(P W F, \mathrm{~m}^{3} \mathrm{GJ}^{-1}\right)$ :

$$
P W F=\frac{E W F}{E G}
$$

where $E G\left(G J \mathrm{yr}^{-1}\right)$ is the amount of electricity generated by the hydropower station over a year.

\subsubsection{Monthly Blue Water Scarcity}

The monthly blue water scarcity (BWS, \%) for a river basin is defined as the ratio of the total blue WF to blue water availability $(N Q-E F R)$, which represents the difference between the natural runoff $\left(A Q+W F_{\text {total }}\right)$ and the environmental flow requirements:

$$
B W S=\frac{W F_{\text {total }}}{A Q+W F_{\text {total }}-E F R}
$$

where $W F_{\text {total }}\left(\mathrm{m}^{3} \mathrm{month}^{-1}\right)$ is the total blue WF for the river basin over a month, $A Q\left(\mathrm{~m}^{3} \mathrm{month}^{-1}\right)$ is the actual runoff in the river basin over the month, the sum of $A Q$ and $W F_{\text {total }}$ equals the natural flow and the EFR $\left(\mathrm{m}^{3}\right.$ month $\left.^{-1}\right)$ is the environmental flow requirements in the river basin over the month.

In this paper, we calculated the BWS for two situations, including and excluding the EWF (including four phases) in the total blue WF in the Yalong River Basin. In the situation including EWF, we further considered the impact of hydropower station construction on environmental flow requirements in different phases and then evaluated the cumulative environmental effects of hydropower stations (The relationship between the degree of hydropower development and utilization in the basin and the 
environment) in the basin. Here, we assumed that $80 \%$ of the natural runoff should be maintained for presumed environmental flow requirements and the BWS for the basin was classified into four categories (Table 2) [28]: low blue water scarcity $(<100 \%)$, in which the total blue WF is less than $20 \%$ of the natural flow, river runoff is unmodified or only slightly modified, and environmental flow requirements are met; moderate blue water scarcity $(100 \%$ to $150 \%)$, in which the total blue WF is between $20 \%$ and $30 \%$ of natural flow, runoff is moderately modified, and environmental flow requirements are not met; significant blue water scarcity (150\% to $200 \%)$, in which the total blue WF is between $30 \%$ and $40 \%$ of natural flow, runoff is significantly modified, and environmental flow requirements are not met; and severe water scarcity ( $>200 \%$ ), in which the total blue WF exceeds $40 \%$ of natural runoff, runoff is seriously modified, and environmental flow requirements are not met $[18,28]$.

Table 2. Four categories of monthly blue water scarcity.

\begin{tabular}{cccc}
\hline$<\mathbf{1 0 0} \%$ & $\mathbf{1 0 0 \% - 1 5 0 \%}$ & $\mathbf{1 5 0 \% - 2 0 0 \%}$ & $>\mathbf{2 0 0} \%$ \\
\hline low blue water scarcity & moderate blue water scarcity & significant blue water scarcity & severe blue water scarcity \\
\hline
\end{tabular}

\section{Results and Discussion}

\subsection{WF of Hydropower Stations}

\subsubsection{EWF of Different Phases}

There are 19 cascade hydropower plants with an installed capacity of 28,105 MW planned for the Yalong River main stream in four phases, namely the established phase I (five hydropower stations), the ongoing phase II (two hydropower stations), the proposed phase III (five hydropower stations), and the planning phase IV (seven hydropower stations). The hydroelectric power WF of the four stages and cumulative phases for the Yalong River Basin are shown in Figure 2. In the figure, the EWF has been reduced from phase I to phase IV, and the value is $243,123,59$, and $42 \mathrm{Mm}^{3}$, respectively. The hydropower stations of the I phase are mainly concentrated in the lower reaches of the Yalong River, including two controlled reservoirs that have a large surface area, resulting in a large water footprint. The cumulative EWF of the four phases gradually increases from 243 to $468 \mathrm{Mm}^{3}$, almost doubled, and hydropower generated increases pressure on local water resources.

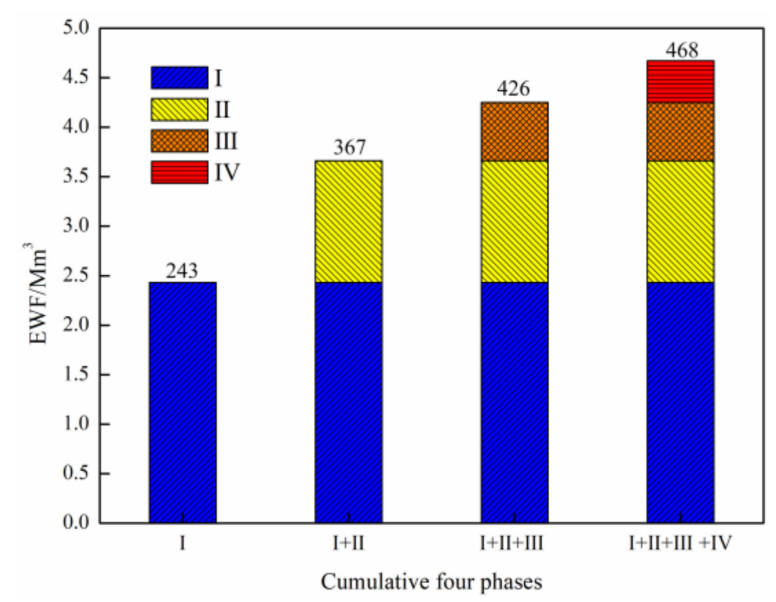

Figure 2. Cumulative water footprint of hydropower stations (EWF, water evaporated from reservoirs) at different phases (four phases: the established phase I, the ongoing phase II, the proposed phase III, and the planning phase IV).

\subsubsection{PWF of Hydropower Stations}

The PWF of hydropower stations for the selected 19 hydropower plants in the Yalong River Basin is presented in Table 1. The average PWF of hydroelectric for the selected plants is $1.20 \mathrm{~m}^{3} \mathrm{GJ}^{-1}$. 
There is a large variation in PWF among the different power plants, ranging from $0.01 \mathrm{~m}^{3} \mathrm{GJ}^{-1}$ for Jinping II to $4.49 \mathrm{~m}^{3} \mathrm{GJ}^{-1}$ for Yagen I.

According to the principle of consistency for the research method and data, this paper screened and analyzed the present research results, as shown in Table 3. The present research included the PWF of the hydropower stations at various spatial scales (global-level, national-level, provincial-level, and basin-level), and the PWFs in different regions were very different. In the present study, the maximum and minimum PWF was the Zhanggang hydropower station and the Hongyi hydropower station in the Yangtze River basin of China, with values of $4234 \mathrm{~m}^{3} \mathrm{GJ}^{-1}$ and $0.001 \mathrm{~m}^{3} \mathrm{GJ}^{-1}$, respectively. The Zhanggang hydropower station has a larger reservoir surface area $\left(13.2 \mathrm{~km}^{2}\right)$. However, the annual power generation is very small, which is only $1 \mathrm{GWh}$. Thus, its PWF is far greater than other hydropower stations. Hongyi hydropower station has a large annual power generation $(369 \mathrm{Gwh})$, but the water surface area of the reservoir is very small. Thus, its water footprint is much smaller than other hydropower stations [18]. It also can be seen from Table 3 that the average PWF in the Yalong River Basin is smaller than the PWF at the other study area, indicating that the water use efficiency of hydropower development in the Yalong River Basin is greater than that of other basins and regions. This is because the cascade hydropower stations of the Yalong River Basin mainly use water flow gravitational potential energy to generate electricity.

Table 3. Comparison of product water footprint (PWF, water consumption per unit of electricity production) of hydroelectric in the present study $/ \mathrm{m}^{3} \mathrm{GJ}^{-1}$.

\begin{tabular}{|c|c|c|c|c|c|c|}
\hline \multicolumn{3}{|c|}{$\mathrm{PWF} / \mathrm{m}^{3} \mathrm{GJ}^{-1}$} & \multirow{2}{*}{ Study Area } & \multirow{2}{*}{ Spatial Scale } & \multirow{2}{*}{$\begin{array}{c}\text { Number of } \\
\text { Hydropower Stations }\end{array}$} & \multirow{2}{*}{ Source } \\
\hline Min & $\operatorname{Max}$ & Average & & & & \\
\hline 0.01 & 56.00 & 1.50 & California, State & Provincial-level & / & Gleick (1994) [27] \\
\hline 0.75 & 5.01 & 8.86 & North Island of New Zealand & \multirow{2}{*}{ National-level } & 9 & Herath (2011) [24] \\
\hline 0.80 & 32.48 & 2.17 & South Island of New Zealand & & 8 & Herath (2011) [24] \\
\hline 0.28 & 166.67 & 6.94 & Global & Global-level & / & Pfister (2011) [22] \\
\hline 0.30 & 846.00 & 68.00 & Global & Global-level & 35 & Mekonnen (2012) [23] \\
\hline 0.40 & 3.58 & 1.51 & Jinsha River Basin, China & Basin-level & 6 & ZHU Yanxia (2013) [33] \\
\hline 0.001 & 4234 & 3.60 & China & National-level & 209 & Junguo Liu (2015) [18] \\
\hline / & / & 6.75 & China & National-level & 283 & HE Yang (2015) [34] \\
\hline 1.15 & 5.35 & 2.23 & Lancang River Basin, China & Basin-level & 8 & YUAN XU (2018) [35] \\
\hline 0.01 & 2.91 & 1.13 & Yalong River Basin, China & Basin-level & 19 & This study \\
\hline
\end{tabular}

In this paper, the average PWF of hydropower stations was $1.13 \mathrm{~m}^{3} \mathrm{GJ}^{-1}$, which was 5.65 times the original coal-water footprint, close to the PWF of crude oil (Table 4). Renewable energy plays an important role in resisting global warming and energy crises, such as hydropower and biomass, but they also provide enormous water stress and threaten local water security while producing energy. Therefore, hydropower development needs to take into account the relationship among water, energy, and environment (i.e., water-energy-environment nexus).

Table 4. Comparison of product water footprint (PWF) of different energy types $/ \mathrm{m}^{3} \mathrm{GJ}^{-1}$.

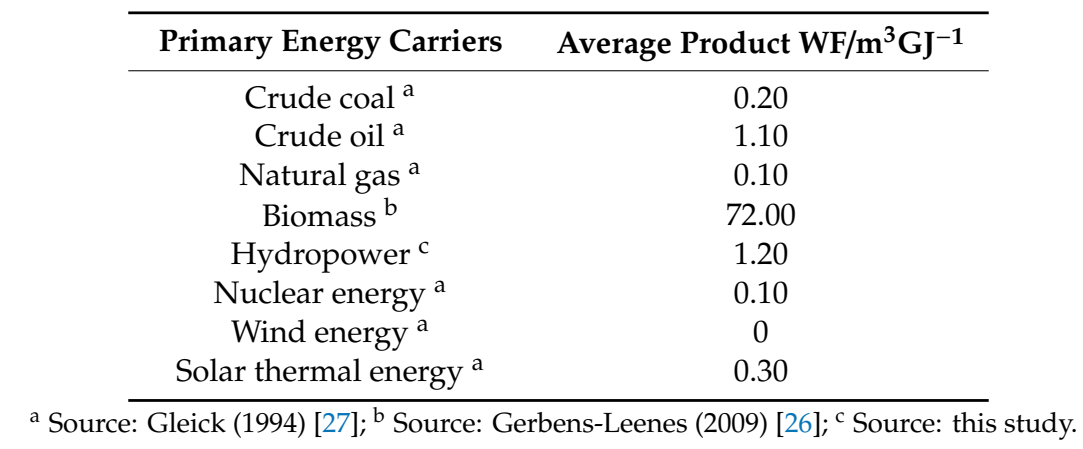




\subsection{Analysis of Influencing Factors}

The PWF is related to many factors, such as energy efficiency factors (water surface area per unit installed capacity, ha $\mathrm{MW}^{-1}$ ), topographic factors (average water depth in the reservoir area, $\mathrm{m}$ ), and climatic factors (evaporation depth, $\mathrm{mm}$ ) $[18,23]$. The correlation between energy efficiency factors, topographic factors, and PWF of hydroelectric is shown in Figures 3 and 4.

From Figure 3, the average energy efficiency factor of the 19 hydropower stations was $1.88 \mathrm{ha} \mathrm{MW}^{-1}$. There was a large variation in energy efficiency factor among the different power plants, ranging from

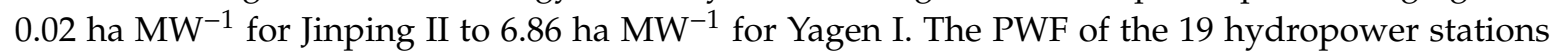
in the basin had a perfect correlation with the energy efficiency factor $\left(R^{2}=0.9649\right)$, indicating that hydropower stations with large energy efficiency factors usually have larger PWF than hydropower stations with smaller energy efficiency factors.

From Figure 4, the PWF of the 19 hydropower stations in the basin had a very poor correlation with topographic factor $\left(R^{2}=0.1073\right)$, indicating that the PWF in Yalong River Basin was less affected by the topographic factor.

The 19 reservoirs have an evaporation depth between 903.97 and $1454.43 \mathrm{~mm} \mathrm{yr}^{-1}$. Reservoirs on the upstream generally have a similar evaporation rate than reservoirs on the downstream, and the maximum value was 1.61 times the minimum value (Table 1). Therefore, the differences between the PWFs of different hydropower stations were mainly related to the energy efficiency factor.

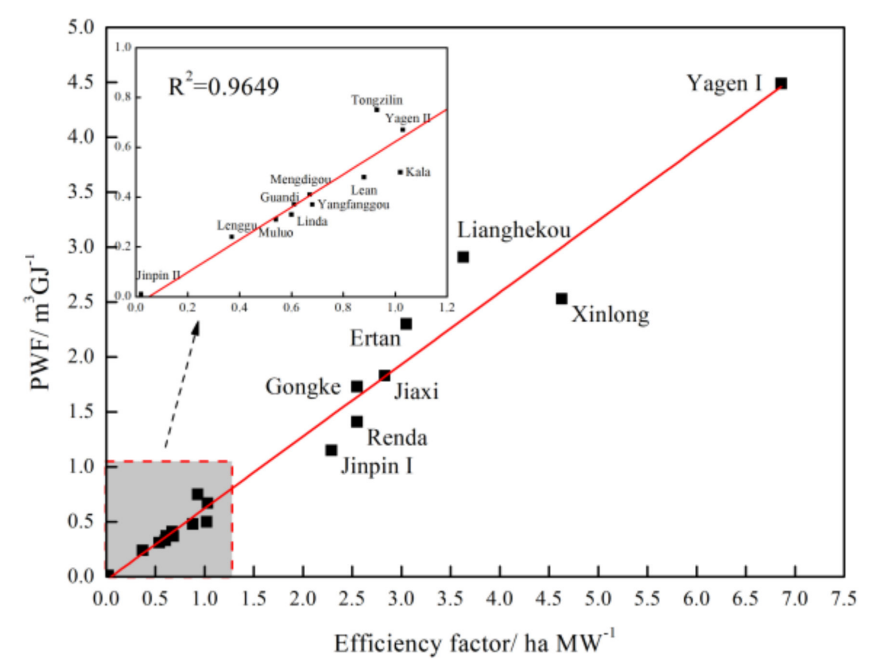

Figure 3. Relationship between product water footprint (PWF) and efficiency factor.

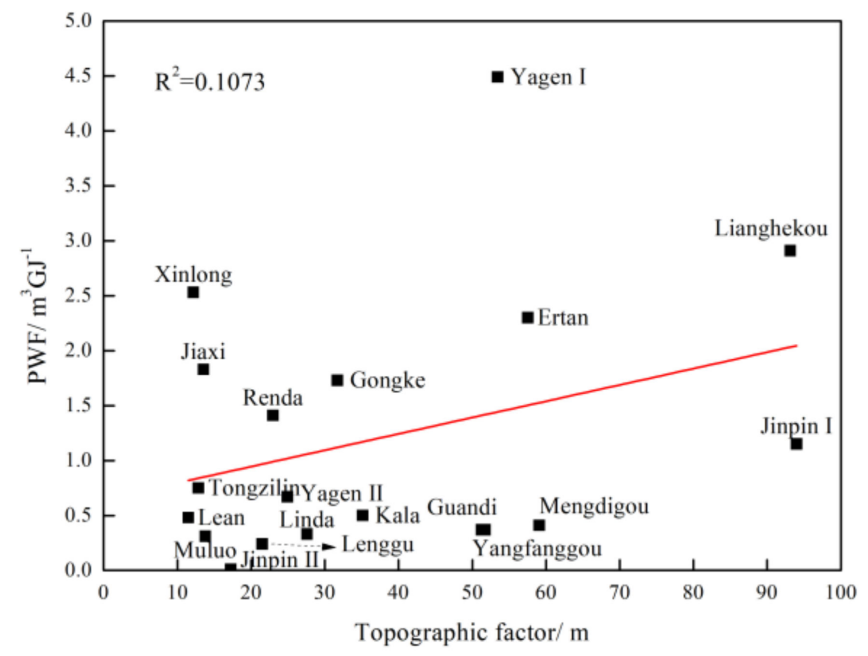

Figure 4. Relationship between product water footprint (PWF) and topographic factor. 


\subsection{Monthly Blue Water Scarcity}

The monthly blue water scarcity (BWS) in the Yalong River Basin for 2015 is shown in Figure 5. The cumulative environmental effects of hydropower stations for the four phases did not cause significant changes in the local WS, both less than $100 \%$ (low blue water scarcity), in which the total blue WF was less than $20 \%$ of the natural flow, river runoff was unmodified or only slightly modified, and environmental flow requirements were met. The difference in BWS between the months of the year was significant. In September, BWS was the smallest, at $12.40 \%$. In December, BWS was the largest, at $64.41 \%$, but not exceeding $100 \%$. It shows that the cumulative environmental effects of development and utilization of cascade hydropower stations in the basin did not affect the local environmental flow requirements in 2015.

Considering the most unfavorable situation, the year 2006 was especially dry in the Yalong River Basin. The BWS in the basin during 2006 was less than 100\%, and the highest was in April and December, close to $80 \%$, which was low blue water scarcity $(<100 \%)$ (Figure 6). It shows that the cumulative environmental effects of development and utilization of cascade hydropower stations in the basin did not affect the local environmental flow requirements in 2006.

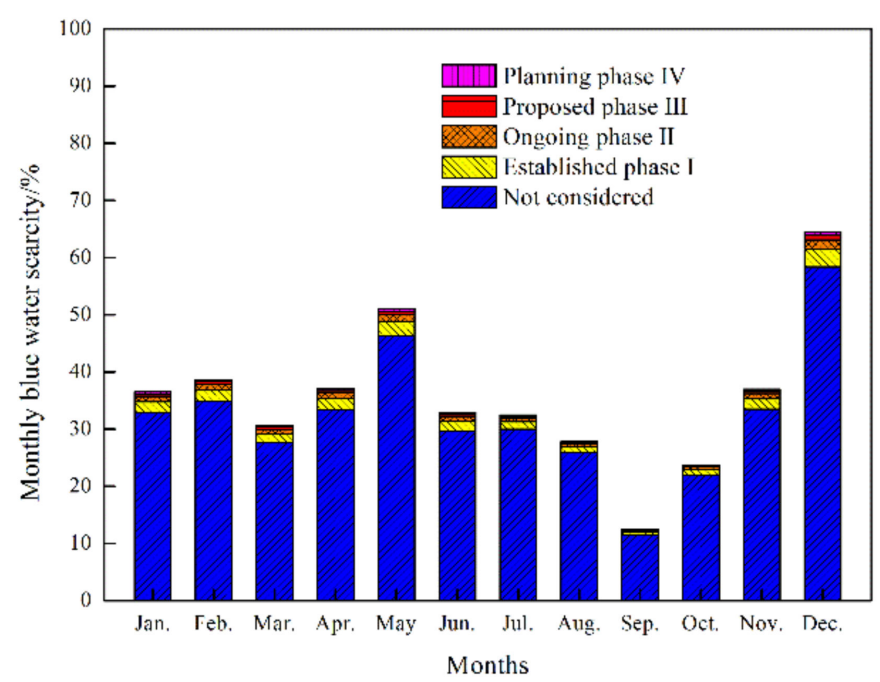

Figure 5. The monthly blue water scarcity (BWS, the ratio of the total blue WF to blue water availability) in the Yalong River Basin in 2015.

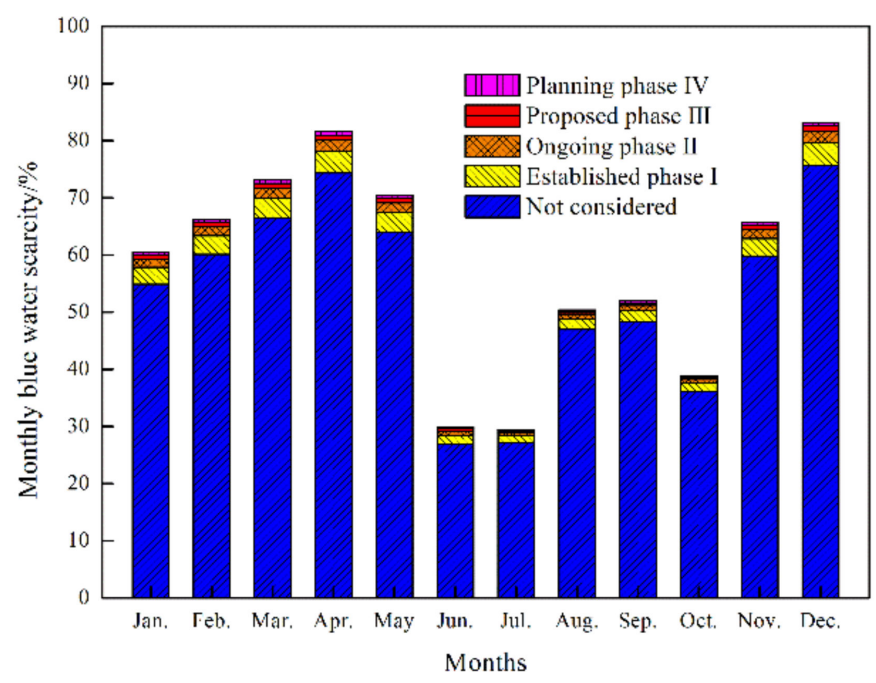

Figure 6. The monthly blue water scarcity (BWS) in the Yalong River Basin in 2006. 
Thus, the BWS belongs to low blue water scarcity $(<100 \%)$ with or without considering the EWFs of the four phases of the hydropower station hydropower stations in the Yalong River Basin, which means that the development and utilization of cascade hydropower stations in the basin did not affect the local environmental flow requirements from the perspective of water footprint. However, the river basins with poor water resources suffered from a moderate to severe water scarcity when the EWF was considered, such as Haihe and Huaihe River Basin in China [18]. Therefore, when assessing the blue WS in basins or regions, it is necessary to consider EWF.

Monthly blue water scarcity depends on many factors, such as blue water consumption, water management, climate change (temperature and rainfall), human activities, and socio-economic development. In this paper, blue water consumption is quantitated by the concept of the water footprint, which refers to blue water consumption in different sectors, including the agricultural sector, industrial sector, residents' living sector, and eco-environment sector (Table 5). From the table it can be observed the agricultural sector is the largest water consumption sector, accounting for about $80 \%$ of the total. Water management, human activities, and socio-economic development are the factors that can influence the blue water scarcity, but these factors were also included in the estimation of water footprint. Climate change factors (temperature and rainfall) are reflected in watershed runoff, and the watershed outlet section runoff is shown in Table 6. From the table, we can see that the difference in runoff between different months of the year was remarkable in 2006 and 2015, which also explained the difference in BWS.

Table 5. The blue water consumption in different sectors among 2006 and 2015/10 $\mathrm{m}^{3}$.

\begin{tabular}{ccccccccc}
\hline Month & $\begin{array}{c}\text { Agricultural } \\
\text { Sector }\end{array}$ & $\begin{array}{c}\text { Industrial } \\
\text { Sector }\end{array}$ & $\begin{array}{c}\text { Residents' } \\
\text { Living Sector }\end{array}$ & $\begin{array}{c}\text { Eco-Environment } \\
\text { Sector }\end{array}$ & $\begin{array}{c}\text { Established } \\
\text { Phase I }\end{array}$ & $\begin{array}{c}\text { Ongoing } \\
\text { Phase II }\end{array}$ & $\begin{array}{c}\text { Proposed } \\
\text { Phase III }\end{array}$ & $\begin{array}{c}\text { Planning } \\
\text { Phase IV }\end{array}$ \\
\hline 1 & 2.62 & 0.32 & 0.11 & 0.10 & 0.20 & 0.10 & 0.05 \\
2 & 2.62 & 0.32 & 0.11 & 0.11 & 0.20 & 0.10 & 0.05 \\
3 & 2.62 & 0.32 & 0.11 & 0.14 & 0.20 & 0.10 & 0.05 \\
4 & 2.62 & 0.32 & 0.11 & 0.16 & 0.20 & 0.10 & 0.05 \\
5 & 2.62 & 0.32 & 0.11 & 0.17 & 0.20 & 0.10 & 0.05 \\
6 & 2.62 & 0.32 & 0.11 & 0.16 & 0.20 & 0.10 & 0.05 \\
7 & 3.71 & 0.32 & 0.11 & 0.17 & 0.20 & 0.10 & 0.05 \\
8 & 4.09 & 0.32 & 0.11 & 0.17 & 0.20 & 0.10 & 0.05 \\
9 & 4.05 & 0.32 & 0.11 & 0.15 & 0.20 & 0.10 & 0.04 \\
10 & 3.91 & 0.32 & 0.11 & 0.13 & 0.20 & 0.10 & 0.04 \\
11 & 2.80 & 0.32 & 0.11 & 0.11 & 0.20 & 0.10 & 0.04 \\
12 & 2.62 & 0.32 & 0.11 & 0.10 & 0.20 & 0.10 & 0.05 \\
\hline
\end{tabular}

Table 6. The runoff of the watershed outlet section in the Yalong River Basin $/ 10^{8} \mathrm{~m}^{3}$.

\begin{tabular}{ccccccccccccc}
\hline Year & $\mathbf{1}$ & $\mathbf{2}$ & $\mathbf{3}$ & $\mathbf{4}$ & $\mathbf{5}$ & $\mathbf{6}$ & $\mathbf{7}$ & $\mathbf{8}$ & $\mathbf{9}$ & $\mathbf{1 0}$ & $\mathbf{1 1}$ & $\mathbf{1 2}$ \\
\hline 2006 & 26.70 & 24.19 & 21.73 & 19.19 & 22.85 & 58.90 & 77.49 & 46.60 & 44.50 & 59.43 & 25.66 & 18.43 \\
2015 & 46.73 & 44.13 & 57.11 & 46.73 & 32.97 & 53.03 & 69.72 & 88.64 & 202.87 & 100.51 & 48.58 & 24.89 \\
\hline
\end{tabular}

\section{Conclusions}

The traditional water resource index "water intake" can no longer truly measure the water consumption of cascade hydropower stations and their positive and negative impacts on the environment, ecology, and society. In this paper, we took the Yalong River Basin as the research object, considered the four phases of hydropower development in the basin, calculated the evaporated water footprint (EWF), product water footprint (PWF), and the blue water scarcity (BWS), analyzed its influencing factors, and evaluated the cumulative environmental effects of hydropower stations based on the water footprint method. Two main conclusions are summarized:

(a) The EWFs in established, ongoing, proposed, and planning phases of the 19 hydropower stations were $243,123,59$, and $42 \mathrm{Mm}^{3}$, respectively. The PWF of the 19 hydropower stations in the Yalong River Basin was 0.01 to $4.49 \mathrm{~m}^{3} \mathrm{GJ}^{-1}$, the average water footprint was $1.20 \mathrm{~m}^{3} \mathrm{GJ}^{-1}$, and the water use efficiency of hydropower development in the basin was greater than that of other basins and 
regions. The differences between the PWF of different hydropower stations were mainly related to the energy efficiency factor.

(b) The BWS belongs to low blue water scarcity $(<100 \%)$ with or without considering the EWF of the four phases of the hydropower station hydropower stations in Yalong River Basin, which means that the cumulative environmental effects of development and utilization of cascade hydropower stations in the basin will not affect the local environmental flow requirements from the perspective of water footprint.

Our study has several limitations. First, cascade reservoirs with good reservoir regulation performance can reduce the risks of devastating floods in downstream regions and protect people's lives and property. Unfortunately, these beneficial impacts were not reflected in this paper, as it is beyond the scope of our study. Second, the consumption of blue water of reservoirs in different months during the year was averaged in this paper. Actually, the consumption of blue water from reservoirs was different for different months over a year because the climate is seasonal. However, the effect was acceptable compared to the total blue water consumption. Third, we assumed that $80 \%$ environmental flow requirement equals $80 \%$ of the natural runoff in the Yalong River Basin. The environmental flow requirement was determined by factors such as natural geographical conditions and environmental conditions necessary for living and social and economic conditions. Therefore, different river basins will have different environmental flow requirements.

Author Contributions: All authors make significant contributions to this article. Conceptualization, L.Y.; Formal analysis, L.Y., B.J. and S.W.; Funding acquisition, L.Y. and S.W.; Investigation, X.W. and P.X.; Methodology, L.Y.; Supervision, J.D. and F.W.; Writing—original draft, L.Y. and B.J.; Writing—review \& editing, L.Y., B.J., and L.M.

Funding: This research was jointly funded by the National Key R\&D Program of China (2017YFC0404605) and the National Natural Science Foundation of China (51709178).

Acknowledgments: We are grateful to the anonymous reviewers for their constructive comments and helpful suggestions.

Conflicts of Interest: The authors declare no conflict of interest.

\section{References}

1. Jiang, T.; Shen, Z.; Liu, Y.; Hou, Y. Carbon Footprint Assessment of Four Normal Size Hydropower Stations in China. Sustainability 2018, 10, 2018. [CrossRef]

2. Li, X.-Z.; Chen, Z.-J.; Fan, X.-C.; Cheng, Z.-J. Hydropower development situation and prospects in China. Renew. Sustain. Energy Rev. 2018, 82, 232-239. [CrossRef]

3. Auestad, I.; Nilsen, Y.; Rydgren, K. Environmental Restoration in Hydropower Development-Lessons from Norway. Sustainability 2018, 10, 3358. [CrossRef]

4. Lindström, A.; Ruud, A. Whose Hydropower? From Conflictual Management into an Era of Reconciling Environmental Concerns; A Retake of Hydropower Governance towards Win-Win Solutions? Sustainability 2017, 9, 1262. [CrossRef]

5. Tang, X.; Li, Q.; Wu, M.; Tang, W.; Jin, F.; Haynes, J.; Scholz, M. Ecological Environment Protection in Chinese Rural Hydropower Development Practices: A Review. Water Air Soil Pollut. 2012, 223, 3033-3048. [CrossRef]

6. Fan, H.; He, D.; Wang, H. Environmental consequences of damming the mainstream Lancang-Mekong River: A review. Earth Sci. Rev. 2015, 146, 77-91. [CrossRef]

7. Xingang, Z.; Lu, L.; Xiaomeng, L.; Jieyu, W.; Pingkuo, L. A critical-analysis on the development of China hydropower. Renew. Energy 2012. [CrossRef]

8. Magilligan, F.J.; Nislow, K.H.J.G. Changes in hydrologic regime by dams. Geomorphology 2005, 71, 61-78. [CrossRef]

9. Ligon, F.K.; Dietrich, W.E.; Trush, W.J.J.B. Downstream ecological effects of dams: A geomorphic perspective. BioScience 1995, 45, 183-192. [CrossRef]

10. Renã-Fãlt, B.M.; Jansson, R.; Nilsson, C. Effects of hydropower generation and opportunities for environmental flow management in Swedish riverine ecosystems. Freshw. Biol. 2010, 55, 49-67. [CrossRef]

11. Niu, S.; Insley, M. On the economics of ramping rate restrictions at hydro power plants: Balancing profitability and environmental costs. Energy Econ. 2013, 39, 39-52. [CrossRef] 
12. Fu, B.; Wang, Y.K.; Xu, P.; Yan, K.; Li, M. Value of ecosystem hydropower service and its impact on the payment for ecosystem services. Sci. Total Environ. 2014, 472, 338-346. [CrossRef] [PubMed]

13. Kataria, M. Willingness to pay for environmental improvements in hydropower regulated rivers. Energy Econ. 2009, 31, 69-76. [CrossRef]

14. Liu, J.; Zang, C.; Tian, S.; Liu, J.; Yang, H.; Jia, S.; You, L.; Liu, B.; Zhang, M. Water conservancy projects in China: Achievements, challenges and way forward. Global Environ. Change Human Policy Dimens. 2013, 23, 633-643. [CrossRef]

15. Wu, M.; Ge, W.; Li, Z.; Wu, Z.; Zhang, H.; Li, J.; Pan, Y. Improved Set Pair Analysis and Its Application to Environmental Impact Evaluation of Dam Break. Water 2019, 11, 821. [CrossRef]

16. Li, Z.; Li, W.; Ge, W. Weight analysis of influencing factors of dam break risk consequences. Nat. Hazards Earth Syst. Sci. 2018, 18, 3355-3362. [CrossRef]

17. Aguilar, S.; Louw, K.; Neville, K. In Proceedings of the IHA World Congress Bulletin, International Institute for Sustainable Development (IISD) and International Hydropower Association (IHA). Iguaçu, Brazil, 13-17 June 2011; Issue 1, Volume 139, No. 5. Available online: www.iisd.ca/ymb/hydro/iha2011 (accessed on 25 October 2019).

18. Liu, J.; Zhao, D.; Gerbens-Leenes, P.W.; Guan, D. China's rising hydropower demand challenges water sector. Sci. Rep. 2015, 5, 11446. [CrossRef]

19. Zhuo, L.; Hoekstra, A.Y.; Wu, P.; Zhao, X.J.S. Monthly blue water footprint caps in a river basin to achieve sustainable water consumption: The role of reservoirs. Water Manag. 2019, 650, 891-899. [CrossRef]

20. Hoekstra, A.Y. Virtual water trade: A quantification of virtual water flows between nations in relation to international crop trade. Water Sci. Technol. 2003, 49, 203-209. [CrossRef]

21. Bakken, T.H.; Killingtveit, A.; Engeland, K.; Alfredsen, K.; Harby, A. Water consumption from hydropower plants-Review of published estimates and an assessment of the concept. Hydrol. Earth Syst. Sci. 2013, 17, 3983-4000. [CrossRef]

22. Pfister, S.; Saner, D.; Koehler, A. The environmental relevance of freshwater consumption in global power production. Int. J. Life Cycle Assess. 2011, 16, 580-591. [CrossRef]

23. Mekonnen, M.M.; Hoekstra, A.Y. The blue water footprint of electricity from hydropower. Hydrol. Earth Syst. Sci. 2012, 16, 179-187. [CrossRef]

24. Herath, I.; Deurer, M.; Horne, D.; Singh, R.; Clothier, B. The water footprint of hydroelectricity: A methodological comparison from a case study in New Zealand. J. Clean. Prod. 2011, 19, 1582-1589. [CrossRef]

25. Xie, X.; Jiang, X.; Zhang, T.; Huang, Z. Regional water footprints assessment for hydroelectricity generation in China. Renew. Energy 2019, 138, 316-325. [CrossRef]

26. Gerbens-Leenes, P.W.; Hoekstra, A.Y.; van der Meer, T. The water footprint of energy from biomass: A quantitative assessment and consequences of an increasing share of bio-energy in energy supply. Ecol. Econ. 2009, 68, 1052-1060. [CrossRef]

27. Gleick, P.H. Water and Energy. Annu. Rev. Energy Environ. 1994, 19, 267-299. [CrossRef]

28. Hoekstra, A.Y.; Mekonnen, M.M.; Chapagain, A.K.; Mathews, R.E.; Richter, B.D. Global monthly water scarcity: Blue water footprints versus blue water availability. PLoS ONE 2012, 7, e32688. [CrossRef]

29. Zeng, Z.; Liu, J.; Koeneman, P.H.; Zarate, E.; Hoekstra, A.Y. Assessing water footprint at river basin level: a case study for the Heihe River Basin in northwest China. Hydrol. Earth Syst. Sci. 2012, 16, 2771-2781. [CrossRef]

30. Schyns, J.F.; Hoekstra, A.Y. The added value of water footprint assessment for national water policy: A case study for Morocco. PLoS ONE 2014, 9, e99705. [CrossRef]

31. Mekonnen, M.; Pahlow, M.; Aldaya, M.; Zarate, E.; Hoekstra, A. Sustainability, Efficiency and Equitability of Water Consumption and Pollution in Latin America and the Caribbean. Sustainability 2015, 7, 2086-2112. [CrossRef]

32. Wang, Y.; Lei, X.; Wen, X.; Fang, G.; Tan, Q.; Tian, Y.; Wang, C.; Wang, H. Effects of damming and climatic change on the eco-hydrological system: A case study in the Yalong River, Southwest China. Ecol. Indic. 2018. [CrossRef]

33. Zhu, Y.; Ji, C.; Zhou, T.; Cao, Y.; Zhang, Y.; Yu, S. Water footprint analysis of generation operation of cascade hydropower stations. Water Resour. Power 2013, 31, 87-90. (In Chinese) 
34. He, Y.; Ji, C.; Shi, P. Calculation analysis and discussion of blue water footprint for hydropower station. Water Resour. Power 2015, 33, 37-41. (In Chinese)

35. Yuan, X.; Lu, Y.; He, K. Research on water footprint of hydropower in middle-lower reaches of Lancangjing River. Water Resour. Power 2018, 36, 37-39. (In Chinese)

(C) 2019 by the authors. Licensee MDPI, Basel, Switzerland. This article is an open access article distributed under the terms and conditions of the Creative Commons Attribution (CC BY) license (http://creativecommons.org/licenses/by/4.0/). 